\title{
Antimalarial Activity of Crude Extract and Solvent Fractions of the Leaves of Bersama abyssinica Fresen. (Melianthaceae) against Plasmodium berghei Infection in Swiss Albino Mice
}

\author{
Agumas Alemu Alehegn, ${ }^{1}$ Jibril Seid Yesuf $\mathbb{D}^{2},{ }^{2}$ and Eshetie Melese Birru ${ }^{2}{ }^{2}$ \\ ${ }^{1}$ Department of Pharmacy, Lumame Primary Hospital, Lumame, Ethiopia \\ ${ }^{2}$ Department of Pharmacology, School of Pharmacy, College of Medicine and Health Sciences, University of Gondar, \\ Gondar, Ethiopia \\ Correspondence should be addressed to Eshetie Melese Birru; meshetie21@gmail.com
}

Received 10 March 2020; Accepted 14 May 2020; Published 9 June 2020

Guest Editor: Lei Xu

Copyright (C) 2020 Agumas Alemu Alehegn et al. This is an open access article distributed under the Creative Commons Attribution License, which permits unrestricted use, distribution, and reproduction in any medium, provided the original work is properly cited.

\begin{abstract}
Background. Treatment of malaria has been compromised by the emergence of drug-resistant parasites. Consequently, novel agents are urgently needed from different sources including from medicinal plants. Thus, the current study aimed at evaluating the antimalarial activity of crude extract and solvent fractions of the leaves of Bersama abyssinica (B. abyssinica) against Plasmodium berghei infection in Swiss Albino mice. Method. A 4-day suppressive test was employed to evaluate the antimalarial effect of crude extract and solvent fractions against early infection. The curative and prophylactic effects of crude extract and fraction with the highest chemosuppression were further tested by Rane's test and residual infection procedure. Parasitemia, survival time, packed cell volume (PCV), body weight, and rectal temperature of mice were used as evaluation parameters. Windows SPSS version 20 was used to analyze the data and analysis of variance (ANOVA) followed by Tukey's post hoc test was used to compare data between groups. Results. The crude extract and aqueous fraction significantly $(P<0.05$ to 0.001$)$ suppressed parasitemia followed by protection of PCV reduction resulting in prolonging the survival time but failed to protect body weight and rectal temperature reduction in all tested models. The ethyl acetate and chloroform fractions also showed significant chemosuppression and PCV protection in the 4 -day suppressive test. The crude extract exhibited a chemosuppression of $49.51 \%, 57.94 \%$, and $44.11 \%$ while the aqueous fraction showed suppression of $47.69 \%, 51.62 \%$, and $37.07 \%$ in 4-day suppressive, curative, and prophylactic tests, respectively, at $400 \mathrm{mg} / \mathrm{kg}$. Conclusion. The crude extract and fractions showed fairly moderate antimalarial activity, and the finding supports the traditional claims and previous in vitro studies. Thus, this may call for further studies to isolate chemical entities for additional safety and efficacy tests.
\end{abstract}

\section{Background}

Malaria is the most prevalent and devastating mosquitoborne infectious disease. It is a major cause of morbidity and mortality throughout tropical and subtropical regions of the world, where the temperature and rainfall are suitable for the development of vectors and parasites [1]. An estimated 228 million cases and 405,000 deaths of malaria occurred worldwide in 2018. Almost $80 \%$ of all malaria cases and deaths globally were in the African region and in India [2]. The burden of disease can be exceptionally high among the most vulnerable groups, such as children $<5$ years old, pregnant women, and migrant laborers traveling to endemic areas, especially when worsening nutritional conditions impair their capacity to fight the disease [3].

Malaria is also the major public health problem in Ethiopia and it is prevalent in over $75 \%$ of the country's area. Approximately $68 \%$ of the Ethiopian population have been estimated to live in areas of $<2,000 \mathrm{~m}$ of altitude and, thus, are considered to be at risk of malaria $[2,4]$. P. falciparum and $P$. vivax are the most dominant malaria parasites in Ethiopia and they are prevalent in all malarious areas in the 
country accounting for $60-70 \%$ and $30-40 \%$ of malaria cases, respectively, although their relative composition can be variable. $P$. malariae and $P$. ovale are rare and account for $<1 \%$ of all confirmed malaria cases [5].

Due to the prevalence of malaria as well as the growing incidence of deaths coupled with the alarming rate of resistance to antimalarial drugs and pesticides, restriction in the use of chemical sprays, adverse reactions of antimalarial drugs, inaccessibility, the problem of affordability, the drying out of new antimalarial drug pipeline, lack of an effective vaccine, and the limited number of effective antimalarial drugs, discovering new antimalarial compound is more than ever a priority [6]. So, new antimalarial agents that are safe, more effective, and affordable with broad therapeutic potential, structurally distinct from existing drugs, and being readily available with a novel mode of action are urgently needed [7]. These have stimulated the search for new pharmacologically active agents that can overcome these barriers from natural products, because history reveals that both quinine [8] and artemisinin [9] have been derived from traditional medicine and plant extracts.

The studied plant, B. abyssinica Fresen. (Melianthaceae), is a species of small- or medium-sized evergreen shrub to a small tree of 6-9 m, rarely exceeding $25 \mathrm{~m}$ in height. In Ethiopian traditional medical practices, where it is commonly identified as azamirr, the dried and powdered leaves of the plant [10], decoction of stem barks, leaves and roots $[11,12]$, and homogenization of the leaves [13] have been reported for the management of malaria. The decoction of the stem bark, leaves, and roots in Tanzania [14], chewing leaves and seeds in Kenya [15], and the leaf parts in central west Ivory Coast [16] have been also reported for malaria management. The stem bark extract has been reported to have substantial in vitro antiplasmodial activity with $86.67 \pm 11.32 \%$ of inhibition rate against chloroquine-resistant P. falciparum Dd2 malaria parasite strain at $100 \mu \mathrm{g} /$ $\mathrm{ml}$ of the $80 \%$ ethanol crude extract [14] and good antimalarial activity against $P$. falciparum FCA-20/Eth strain with IC50 of $11 \mu \mathrm{g} / \mathrm{ml}$ [17]. On the other hand, ethanol extract of the leaves has been reported to have moderate in vitro antiplasmodial activity $(\mathrm{IC} 50=23.9 \pm 5.7 \mu \mathrm{g} / \mathrm{ml})$ against chloroquine-resistant FcB1/Colombia strain of $P$. falciparum [16] and pronounced antimalarial activity against chloroquinesensitive strain (FCA-20/Eth) (IC50=4 $\mathrm{g} / \mathrm{ml}$ ) [17]. Thus, based on ethnobotanical use and in vitro studies mentioned above, the present study evaluated the in vivo antimalarial activity of the crude extract and solvent fractions of the leaves of B. abyssinica.

\section{Materials and Methods}

2.1. Collection of Plant Materials. The leaves of B. abysinica were collected from Tara Gedam, South Gondar Zone, Amhara National Regional State, $85 \mathrm{~km}$ away from Gondar city, in December 2018. The collected plant material was wrapped with plastic sheets during transportation, authentication was done by a botanist in the Biology Department, University of Gondar, and a voucher specimen (voucher no. 001AAA) was deposited in the herbarium of
Department of Biology, University of Gondar, for future reference.

2.2. Experimental Animals and Parasites. A total of 170 healthy, adult Swiss Albino mice of either sex $(25 \pm 5 \mathrm{~g}, 6$ to 8 weeks of age) were purchased from the Ethiopian Public Health Institute (EPHI). The animals were kept in cages and housed in a standard animal house under a natural $12 / 12 \mathrm{~h}$ light-dark cycle at room temperature and provided with pellet diet and water ad libitum in the animal house of the Department of Pharmacology, School of Pharmacy, College of Medicine and Health Sciences, University of Gondar. The mice were maintained and cared as per the international guidelines for the use and maintenance of experimental animals throughout the experiment $[18,19]$. Animals were allowed to acclimatize to the laboratory condition for a week before the beginning of the experiment.

The Plasmodium berghei ANKA strain (chloroquinesensitive) was obtained from EPHI, Addis Ababa, and the parasite was maintained by intraperitoneal serial passage of blood from mouse to mouse.

2.3. Preparation of Plant Material. The collected plant leaves were cleaned with tap water and air-dried at room temperature under a shade and reduced to appropriate size. Then, it was packed in a plastic bag and kept until extraction. The powdered plant materials were weighed by sensitive digital weighing balance (EPH-400 Abron Exports), and a total of 1000 grams of powdered leaves was macerated with $80 \%$ methanol (250 g in $1500 \mathrm{ml}$ ) in Erlenmeyer flask for 72 hours at room temperature. The extraction process was facilitated by occasional shaking. After 72 hours, the extract was separated from the marc using gauze and further filtered by Whatman filter paper No. 1 . The residue was remacerated for another 72 hours two times using the same volume of $80 \%$ methanol. After exhaustive extraction, the combined filtrate was dried by hot air oven (Medit-Medizin Technik, Germany) at $40^{\circ} \mathrm{C}$ to obtain the crude extract of the plant. The extract was further concentrated to dryness by freezedrying using Lyophilizer (LabFreez Instruments, Germany). After drying, the amount of dry extract obtained was harvested and the dried extract was transferred into vials and kept in a desiccator at $-4^{\circ} \mathrm{C}$ until use. The weight of the dry extract was expressed as a percentage of the total mass of dry plant matter to determine the percentage yield [20]. About 80 grams of the crude extract was used for fractionation and the remaining was used for the antimalarial activity evaluation of the crude extract.

2.4. Fractionation. The dried crude $80 \%$ methanolic leaf extract of $B$. abysinica was further fractionated using sequential solvent partitioning by different solvents of increasing polarity (chloroform, ethyl acetate, and water) to get different solvent fractions. Eighty grams of the extract was suspended in $400 \mathrm{ml}$ of distilled water in a separatory funnel. The aqueous portion was partitioned three times with $400 \mathrm{ml}$ of chloroform to obtain chloroform fraction. 
Then, the aqueous residue was further fractionated three times with $400 \mathrm{ml}$ of ethyl acetate to obtain ethyl acetate fraction. In the end, from the remaining aqueous solution, the third fraction, which we call aqueous fraction, was obtained. The first two fractions were dried in an oven under $40^{\circ} \mathrm{C}$, while the aqueous fraction was solidified in a refrigerator overnight and then dried using a Lyophilizer. The \% yield of the dried fractions was calculated, and the fractions obtained were put in airtight bottles and stored in a refrigerator at $-4^{\circ} \mathrm{C}$ until used [21].

2.5. Acute Oral Toxicity Testing. Acute oral toxicity of the crude extract was performed on healthy female Swiss Albino mice as per the OECD-425 guideline limit test procedure [22]. Accordingly, five female albino mice of 6-8 weeks of age were used. All mice were fasted (food but not water) for 3 hours before and 1 hour after the administration of the extract. A limit dose of $2000 \mathrm{mg} / \mathrm{kg}$ was given for the first animal. Based on the outcome of the first mouse, the crude extract was administered for four additional mice. The mice were housed separately and observed for the manifestation of gross behavioral and physical toxicities like changes in the skin, urination, lacrimation, reduction in feeding activity, excitation, paw licking, increased respiratory rate, decreased motor activity, diarrhea, weight loss, and paralysis continuously for the first 30 minutes and intermittently for 4 hours, over a period of 24 hours and later followed for 14 days for an interval of 24 hours for any lethality.

2.6. Grouping and Dosing of Animals. Mice were randomly assigned into three extract-treated groups and two controls, six mice per group for each. Group I was a negative control and received distilled water which was used as a solvent for both the crude and solvent fraction extracts. Groups II, III, and IV were treated with 100,200 , and $400 \mathrm{mg} / \mathrm{kg}$ doses of the extract orally, respectively. The doses of the extract were $1 / 20^{\text {th }}, 1 / 10^{\text {th }}$, and $1 / 5^{\text {th }}$ of the LD50 value from the acute oral toxicity study. Group V was treated with chloroquine $25 \mathrm{mg} /$ $\mathrm{kg}$ via the oral route using oral gavage. The volume administered was calculated based on individual mouse body weight and duration of administration depended on the type of test performed.

2.7. Inoculation of Parasite. Mice were infected by a blood sample collected from a donor mouse with a rising parasitemia of about $20-30 \%$. After the determination of the percentage parasitemia in the donor mouse, it was sacrificed by head blow and blood was collected via incisions of the jugular vein into a test tube containing 3.8\% trisodium citrate added as an anticoagulant. The collected blood was diluted by $0.9 \%$ physiological isotonic saline based on the parasitemia of the donor mice and the RBC count of normal mice $\left(4.5 \times 10^{9} \mathrm{RBC} / \mathrm{ml}\right)$ in such a way that $1 \mathrm{ml}$ blood contains $5 \times 10^{7} P$. berghei-infected erythrocytes. Each mouse to be used in the experiment was injected intraperitoneally with $0.2 \mathrm{ml}$ of infected blood containing about $1 \times 10^{7}$ P. berghei-parasitized erythrocytes [23].
2.8. Four-Day Suppressive Test. This test was conducted to evaluate the schizonticidal activities of the plant material on early $P$. berghei infection in mice as described by Knight and Peters [24]. The infected mice were randomly divided into five groups, and treatment was started three hours after the inoculation of the parasite on day 0 and continued for the next four days from day 0 to day 3 with a 24 -hour time interval between the doses. After giving the treatment for four days, thin blood film was made from the tail of each mouse on the fifth day (D4) to determine the level of parasitemia and percentage inhibition.

2.9. Rane's Test (Curative Test). The curative test was undertaken with the crude extract and aqueous fraction, which showed the highest parasitemia suppression in the 4-day suppressive test. Accordingly, evaluation of the curative potential against an established malaria infection was carried out according to the method described by Ryley and Peters [25]. The mice were injected intraperitoneally with a standard inoculum of $1 \times 10^{7} \mathrm{P}$. berghei-infected erythrocytes on the first day (day 0). Seventy-two hours later, the mice were divided into five groups of six mice per group for both the crude extract and solvent fractions. The mice were treated once daily for 5 days from day 3 to day 7 . Starting from day 3 through day 7 daily, thin blood films were prepared from the tail bleed of each mouse to monitor the level of parasitemia.

2.10. Test for Prophylactic Activity. The prophylactic activity of the crude extract and the aqueous fraction, which showed the highest parasitemia suppression in the 4-day suppressive test, was tested using the residual infection procedure described by Peters [26]. Groups of mice were randomized into five groups of six mice per group for crude extract and aqueous fraction. Treatment was given daily for four days, and all mice were infected with the parasite on the 5th day. Thin blood films were prepared from each mouse after 72 hours of infection to determine the level of parasitemia.

2.11. Determination of Parasitemia. Thin blood smears were prepared from the tail snip of each mouse on the fifth day (D4) for Peter's 4-day suppressive test, after 72 hours of infection on day 8 in the prophylactic test and from day 3 after infection established to day 7 for the curative test on microscopic slides. The slides were dried, fixed with absolute methanol, and stained with $10 \%$ Giemsa at $\mathrm{pH} 7.2$ for 10 minutes, and then, they were washed gently using distilled water and air-dried at room temperature. Finally, the slides were examined under a microscope with an oil immersion objective ( $\times 100$ magnification power) by taking an average of six fields. The parasite count was done by an experimentblinded technician. Percentage parasitemia was calculated by counting infected $\mathrm{RBC}$ and total RBC from Giemsa-stained thin blood films, and the average percentage suppression of parasitemia was calculated for each dose level by comparing the parasitemia in infected controls with that of treated mice with the following formulas [27]: 


$$
\begin{aligned}
& \% \text { parasitemia }=\frac{\text { number of parasitized } \mathrm{RBCs}}{\text { total number of } \mathrm{RBCs}} * 100 \%, \\
& \% \text { suppression }=\frac{(\text { mean parasitemia of negative control }- \text { mean parasitemia of the treated group })}{\text { mean parasitemia of negative contol }} * 100 \% \text {. }
\end{aligned}
$$

2.12. Determination of Mean Survival Time. Mortality was monitored daily and the number of days from the time of inoculation of the parasite up to death was recorded for each mouse in the treatment and control groups throughout the follow-up period of 30 days (D0-D29) for all the models. Mean survival time (MST) for each group was determined arithmetically by calculating the average survival time (days) of mice starting from the date of infection over a period of 30 days (D0-D29). MST for each group was then calculated using the following formula [28]:

MST $=\frac{\text { sum of survival time for all mice in a group (in days) }}{\text { total numbers of mice in that group }}$.

2.13. Packed Cell Volume Determination. Packed cell volume (PCV) is the other antimalarial activity evaluation parameter to assess whether the test substance is effective in preventing hemolysis associated with the invading Plasmodium parasite or not. Blood was collected from the tail of each mouse in heparinized microhematocrit capillary tubes. The capillary tubes were filled to $3 / 4^{\text {th }}$ of their height with blood and sealed at one end with sealing clay. The tubes were then placed in a microhematocrit centrifuge, with the sealed end being outwards and centrifuged for 5 minutes at 11,000 rpm. The tubes were taken out of the centrifuge, and PCV was determined using a standard Micro-Hematocrit Reader. It was measured before inoculating the parasite (day 0 ) and day 4 in Peter's 4-day suppressive test and D0 and D7 in the prophylactic activity test. In the case of Rane's test, PCV was measured on the third day after infection established and on the last day of treatment on the seventh day. PCV is a measure of the proportion of RBCs to plasma in the whole blood and is determined using the relation shown as follows [29]:

$$
\text { PCV }=\frac{\text { volume of erythrocytes in a given volume of blood }}{\text { total blood volume }} \text {. }
$$

\subsection{Determination of Body Weight and Temperature Change.} The body weight of each mouse in all groups was measured on day 0 before infection and day 4 in the four-day suppressive test and D0 and D7 (72 hrs after infection) in the prophylactic activity test while in Rane's test it was measured on day 3 after the infection was established and on day seven, the last day of the treatment, using a sensitive digital weighing balance, to observe whether the test extract of the leave prevents body weight loss that commonly reduced with increasing parasitemia in infected mice. The rectal temperature of each mouse in all groups was measured by a digital thermometer one hour before infection, four hours after infection, and then daily to see the effect of crude extract and solvent fractions on the rectal temperature in the 4-day suppressive test. On the other hand, in Rane's test, rectal temperature was measured one hour before infection and then daily from day 3 to day 7 , and in the prophylactic activity test, rectal temperature was measured on D0 before treatment, D4 before inoculation, and then daily till day 7 .

2.15. Data Management and Statistical Analysis. The results were calculated by Microsoft Excel 2013 and expressed as mean \pm SEM for each group. All the grouped data were statistically evaluated, and the significance of various treatments was calculated using one-way ANOVA followed by Tukey's post hoc test. The results were considered statistically significant at a 95\% confidence level and $P$ value $<0.05$. All data processing was done using SPSS data analysis software version 20 .

\section{Results}

3.1. Yield of Crude Extract and Fractions. As summarized in Table 1, from 120 grams of $80 \%$ methanol crude extract, the aqueous fraction provided the highest yield followed by the chloroform fraction, while the lower yield was obtained from the ethyl acetate fraction.

3.2. Acute Toxicity Test of Crude Extract. The acute toxicity study indicated that the crude extract caused no mortality in a limited dose of $2000 \mathrm{mg} / \mathrm{kg}$ within the first 24 hours as well as for the following 14 follow-up days. Physical and behavioral observations of the experimental mice also revealed no visible signs of overt toxicity. This indicates that LD50 of the extract is greater than $2000 \mathrm{mg} / \mathrm{kg}$.

3.3. Effect of Crude Extract and Solvent Fractions in the 4-Day Suppressive Test. As presented in Table 2, the 80\% methanolic crude extract and all solvent fractions of the leaves of B. abyssinica showed statistically significant $(P<0.05$ to $P<0.001)$ chemosuppressive activity against $P$. berghei infection in mice as compared to the negative control. The highest level of inhibition $(49.51 \%, P<0.001)$ was obtained by $400 \mathrm{mg} / \mathrm{kg}$ dose of the crude extract, followed by the aqueous fraction $(47.69 \%, P<0.001)$ at $400 \mathrm{mg} / \mathrm{kg}$, while the lowest suppression $(28.05 \%, P<0.05)$ was obtained after the administration of $100 \mathrm{mg} / \mathrm{kg}$ dose of the chloroform 
TABLE 1: Yields of $80 \%$ methanol crude extract and solvent fractions.

\begin{tabular}{|c|c|c|c|}
\hline Extract & Color of extract & Actual yield (g) & Percentage yield \\
\hline Methanol $80 \%$ crude extract & & 120 & 12 \\
\hline Ethyl acetate fraction (EA) & & 7.20 & 9 \\
\hline Chloroform fraction $(\mathrm{CH})$ & & 9.15 & 11.44 \\
\hline Aqueous fraction (AQ) & & 56.5 & 70.62 \\
\hline
\end{tabular}

TABle 2: Effect of B. abyssinica crude extract and solvent fractions on the percentage parasitemia and survival time of $P$. berghei-infected mice in the 4-day suppressive test.

\begin{tabular}{|c|c|c|c|}
\hline Group & $\%$ parasitemia $( \pm$ SEM $)$ & \% suppression & MST (days) $( \pm$ SEM $)$ \\
\hline DW $10 \mathrm{ml} / \mathrm{kg}^{*}$ & $33.57 \pm 1.99$ & 0.00 & $6.17 \pm 0.40$ \\
\hline BA $100 \mathrm{mg} / \mathrm{kg}$ & $21.17 \pm 2.25$ & $36.94^{\mathrm{a}, \mathrm{b} 3}$ & $8.67 \pm 0.42^{\mathrm{b} 3}$ \\
\hline BA $200 \mathrm{mg} / \mathrm{kg}$ & $20.18 \pm 2.23$ & $39.89^{\mathrm{a} 3, \mathrm{~b} 3}$ & $10.50 \pm 0.76^{\mathrm{a} 3, \mathrm{~b} 3}$ \\
\hline BA $400 \mathrm{mg} / \mathrm{kg}$ & $16.95 \pm 1.52$ & $49.51^{\mathrm{a} 3, \mathrm{~b} 3}$ & $13.83 \pm 1.05^{\mathrm{a} 3, \mathrm{~b} 3, \mathrm{c} 3, \mathrm{~d} 1}$ \\
\hline CQ $25 \mathrm{mg} / \mathrm{kg}^{*}$ & $0.00 \pm 0.00$ & $100.00^{\mathrm{a} 3}$ & $30.00 \pm 0.00^{\mathrm{a} 3}$ \\
\hline DW $10 \mathrm{ml} / \mathrm{kg}$ & $32.66 \pm 2.59$ & 0.00 & $6.33 \pm 0.62$ \\
\hline AQ $100 \mathrm{mg} / \mathrm{kg}$ & $21.38 \pm 3.67$ & $34.54^{\mathrm{al}, \mathrm{b} 3}$ & $9.33 \pm 1.30^{\mathrm{b} 3}$ \\
\hline AQ $200 \mathrm{mg} / \mathrm{kg}$ & $19.67 \pm 1.08$ & $39.78^{\mathrm{a} 2, \mathrm{~b} 3}$ & $10.50 \pm 0.50^{\mathrm{al}, \mathrm{b} 3}$ \\
\hline AQ $400 \mathrm{mg} / \mathrm{kg}$ & $17.08 \pm 2.26$ & $47.69^{\mathrm{a} 3, \mathrm{~b} 3}$ & $13.60 \pm 1.29^{\mathrm{a} 3, \mathrm{~b} 3, \mathrm{e} 1}$ \\
\hline EA $100 \mathrm{mg} / \mathrm{kg}$ & $20.42 \pm 3.12$ & $37.48^{\mathrm{a} 2, \mathrm{~b} 3}$ & $8.83 \pm 1.40^{\mathrm{b} 3}$ \\
\hline EA $200 \mathrm{mg} / \mathrm{kg}$ & $20.32 \pm 2.13$ & $37.78^{\mathrm{a} 2, \mathrm{~b} 3}$ & $9.17 \pm 1.30^{\mathrm{b} 3}$ \\
\hline EA $400 \mathrm{mg} / \mathrm{kg}$ & $18.98 \pm 0.39$ & $41.89^{\mathrm{a} 2, \mathrm{~b} 3}$ & $12.00 \pm 1.77^{\mathrm{a} 1, \mathrm{~b} 3}$ \\
\hline $\mathrm{CH} 100 \mathrm{mg} / \mathrm{kg}$ & $23.50 \pm 2.13$ & $28.05^{\mathrm{a} 1 \mathrm{~b} 3}$ & $8.17 \pm 1.38^{\mathrm{b} 3}$ \\
\hline $\mathrm{CH} 200 \mathrm{mg} / \mathrm{kg}$ & $22.48 \pm 1.90$ & $31.17^{\mathrm{a} 1 \mathrm{~b} 3}$ & $8.33 \pm 0.95^{\mathrm{b} 3}$ \\
\hline $\mathrm{CH} 400 \mathrm{mg} / \mathrm{kg}$ & $20.18 \pm 2.37$ & $38.21^{\mathrm{a} 2, \mathrm{~b} 3}$ & $9.33 \pm 1.67^{\mathrm{b} 3}$ \\
\hline CQ $25 \mathrm{mg} / \mathrm{kg}^{\circ}$ & $0.00 \pm 0.00$ & $100.00^{\mathrm{a} 3}$ & $30.00 \pm 0.00^{\mathrm{a} 3}$ \\
\hline
\end{tabular}

Data are expressed as mean $\pm \mathrm{SEM} ; n=6, \mathrm{a}=$ compared to $\mathrm{DW}, \mathrm{b}=$ compared to CQ25 mg $/ \mathrm{kg}, \mathrm{c}=$ compared to BA $100 \mathrm{mg} / \mathrm{kg}, \mathrm{d}=\mathrm{compared} \mathrm{to} \mathrm{BA} 200 \mathrm{mg} / \mathrm{kg}$, $\mathrm{e}=$ compared to AQ $100 \mathrm{mg} / \mathrm{kg}, 1=P<0.05,2=P<0.01,3=P<0.001,{ }^{*}=$ negative and positive controls used for crude extract in the 4 -day suppressive test, $\mathrm{DW}=$ distilled water, $\mathrm{BA}=\mathrm{B}$. abyssinica crude extract, $\mathrm{EA}=$ ethyl acetate fraction, $\mathrm{CH}=$ Chloroform fraction, $\mathrm{AQ}=$ aqueous fraction, $\mathrm{CQ}=$ chloroquine, $\mathrm{SEM}=$ standard error of mean, and MST = mean survival time.

fraction. The rank order of chemosuppression of the solvent fractions was aqueous $(47.69 \%, P<0.001)>$ ethyl acetate (41.89\%, $\quad P<0.01)>$ chloroform $(38.21 \%, \quad P<0.01)$ at $400 \mathrm{mg} / \mathrm{kg}$ dose. Comparison among the crude extract- and solvent fraction-treated groups did not show any significant differences. Chemosuppressive activities produced by all doses of crude extract and fractions were significantly $(P<0.001)$ lower than the standard drug, chloroquine $25 \mathrm{mg} / \mathrm{kg}$, which showed $100 \%$ chemosuppression.

The crude extract at 200 and $400 \mathrm{mg} / \mathrm{kg}$ doses prolonged MST of mice significantly (10.50 \pm 0.76 days and $13.83 \pm 1.05$ days, respectively, $P<0.001)$ as compared to the negative control $(6.17 \pm 0.40)$. The aqueous fraction at doses of 200 $(10.50 \pm 0.50$ days, $P<0.05)$ and $400 \mathrm{mg} / \mathrm{kg}(13.67 \pm 1.05$ days $P<0.001)$ as well as the ethyl acetate fraction at a dose of $400 \mathrm{mg} / \mathrm{kg}(12.00 \pm 1.77$ days, $P<0.05)$ also showed statistically significant prolongation of mean survival time when compared with the negative control group $(6.33 \pm 0.62)$. Comparison among the crude extract-treated groups demonstrated that $400 \mathrm{mg} / \mathrm{kg}$ dose increased the survival time of mice significantly as compared to $100 \mathrm{mg} / \mathrm{kg}$ $(P<0.001)$ and $200 \mathrm{mg} / \mathrm{kg}(P<0.05)$ treated groups. Similarly, in the aqueous fraction-treated groups, mice treated at $400 \mathrm{mg} / \mathrm{kg}$ dose survived longer than $100 \mathrm{mg} / \mathrm{kg}$ treated mice $(P<0.05)$. However, statistically significant differences were not observed in the mean survival time of mice among other doses of crude extract- and solvent fraction-treated groups (Table 2).

As indicated in Figure 1, all doses of the crude extract and fractions were able to significantly $(P<0.05, P<0.001)$ prevent the decrease in packed cell volume as compared to the negative control. No apparent difference was observed among the three doses of the crude extract and solvent fractions in protecting the packed cell volume of the mice. The standard drug, in comparison with all doses of the chloroform fraction $(P<0.05)$, did not show notable differences in packed cell volume protection as compared to all doses of the crude extract and other fractions. 


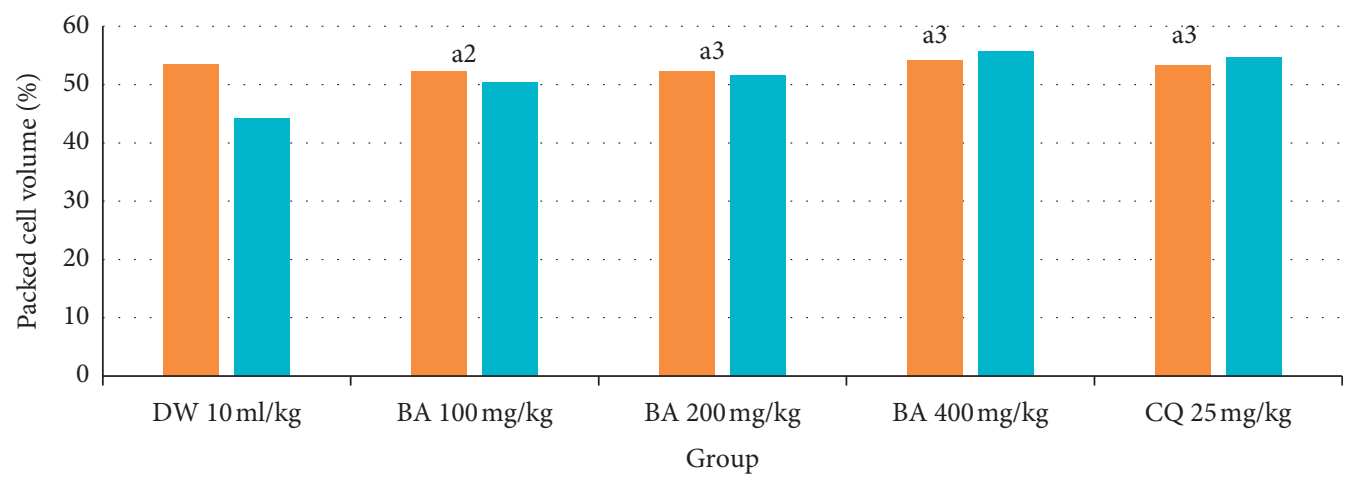

- Packed cell volume (\%) D0

- Packed cell volume (\%) D4

(a)

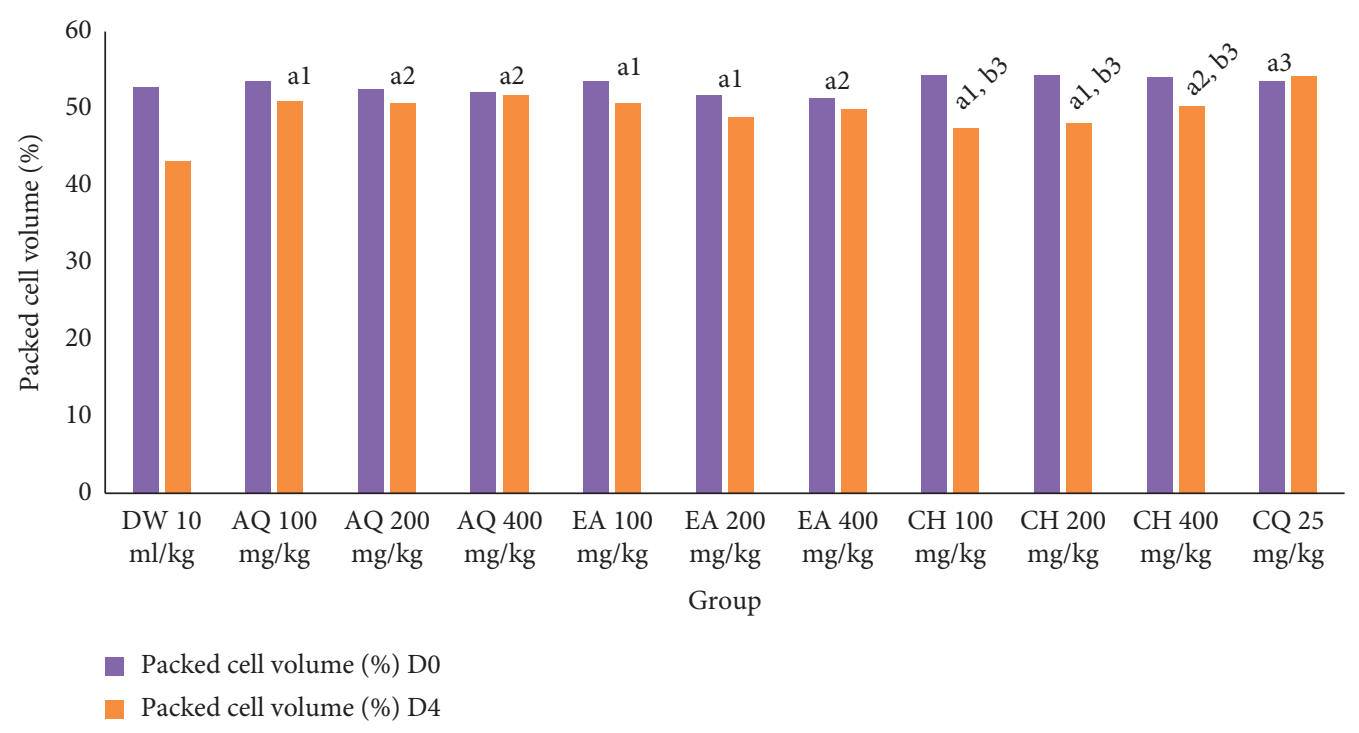

(b)

Figure 1: Effect of B. abyssinica crude extract and solvent fractions on packed cell volume of $P$. berghei-infected mice in 4-day suppressive test. Data are expressed as mean $\pm \mathrm{SEM} ; n=6$, $\mathrm{a}=$ compared to DW, $\mathrm{b}=$ compared to CQ $25 \mathrm{mg} / \mathrm{kg}, 1=P<0.05,2=P<0.01,3=P<0.001$, $\mathrm{DW}=$ distilled water, $\mathrm{BA}=B$. abyssinica crude extract, $\mathrm{EA}=$ ethyl acetate fraction, $\mathrm{CH}=$ Chloroform faction, $\mathrm{AQ}=\mathrm{aqueous}$ fraction, $\mathrm{CQ}=$ chloroquine, $\mathrm{SEM}=$ standard error of mean, $\mathrm{D} 0=$ day $0, \mathrm{D} 4=$ day 4 .

Mice treated with all doses of the crude extract of $B$. abyssinica and solvent fractions had lost some of their body weight and rectal temperature in a non-dose-dependent manner. The crude extract and all the three fractions did not significantly protect the loss in body weight and rectal temperature as compared to the control group (Table 3). There were no significant differences among all doses of the crude extract- and solvent fraction-treated groups in the reduction of body weight and rectal temperature associated with the increasing parasitemia. A significant difference was not also noticed among crude extract- and solvent fractiontreated mice with the standard drug-treated group. However, chloroquine at all doses resulted in a significant reduction in body weight $(P<0.05)$ and rectal temperature $(P<0.01$ and $P<0.001)$ as compared with the chloroform fraction.
3.4. Effect of Crude Extract and Aqueous Fraction in the Curative Test. The crude extract and aqueous fraction with a relatively highest antimalarial activity (aqueous fraction) in the four-day suppressive test were further evaluated for their effect on established parasite infection. As presented in Table 4 , despite the first dose administration on the $3^{\text {rd }}$ day, the parasitemia level was increased on the $4^{\text {th }}$ day with $100 \mathrm{mg} / \mathrm{kg}$ dose of both the crude extract and aqueous fraction. Upon the second dose administration on the $4^{\text {th }}$ day, the parasitemia level began to decline on the $5^{\text {th }}$ day with all the three doses of the crude extract and the aqueous fraction and kept on decreasing across the treatment days. However, the parasitemia in the control group displayed a daily increase from day 3 to day 7. All doses of the crude extract and aqueous fractions showed a significant $(P<0.001)$ curative effect on the $7^{\text {th }}$ day from a thin blood film as compared to the negative control. 
TABLE 3: Effect of B. abyssinica crude extract and solvent fractions on body weight and rectal temperature of $P$. berghei-infected mice in the 4-day suppressive test.

\begin{tabular}{|c|c|c|c|c|c|c|}
\hline \multirow{2}{*}{ Group } & \multicolumn{3}{|c|}{ Body weight $(\mathrm{g}) \pm$ SEM } & \multicolumn{3}{|c|}{ Rectal temperature $\left({ }^{\circ} \mathrm{c}\right) \pm$ SEM } \\
\hline & D0 & $\mathrm{D} 4$ & $\%$ change & D0 & $\mathrm{D} 4$ & $\%$ change \\
\hline DW $10 \mathrm{ml} / \mathrm{kg}^{*}$ & $30.26 \pm 0.55$ & $28.00 \pm 0.58$ & -7.47 & $36.70 \pm 0.30$ & $34.02 \pm 0.22$ & -7.30 \\
\hline BA $100 \mathrm{mg} / \mathrm{kg}$ & $27.42 \pm 1.11$ & $26.42 \pm 0.86$ & -3.89 & $36.68 \pm 0.19$ & $35.25 \pm 0.36$ & -3.77 \\
\hline BA $200 \mathrm{mg} / \mathrm{kg}$ & $28.38 \pm 0.51$ & $27.51 \pm 0.81$ & -3.14 & $36.35 \pm 0.28$ & $34.97 \pm 0.21$ & -3.79 \\
\hline BA $400 \mathrm{mg} / \mathrm{kg}$ & $28.76 \pm 0.81$ & $27.85 \pm 0.95$ & -3.24 & $36.35 \pm 0.28$ & $35.08 \pm 0.18$ & -3.48 \\
\hline CQ $25 \mathrm{mg} / \mathrm{kg}^{*}$ & $27.94 \pm 1.49$ & $28.02 \pm 1.36$ & $0.29^{\mathrm{a} 3}$ & $36.13 \pm 0.71$ & $36.15 \pm 0.15$ & $0.08^{\mathrm{a} 3}$ \\
\hline $\mathrm{DW} 10 \mathrm{ml} / \mathrm{kg}$ & $30.04 \pm 1.78$ & $25.39 \pm 1.24$ & -15.48 & $36.18 \pm 0.12$ & $34.72 \pm 0.32$ & -4.04 \\
\hline AQ $100 \mathrm{mg} / \mathrm{kg}$ & $26.99 \pm 0.76$ & $24.38 \pm 0.53$ & -8.27 & $36.48 \pm 0.23$ & $35.88 \pm 0.22$ & -1.64 \\
\hline AQ $200 \mathrm{mg} / \mathrm{kg}$ & $28.48 \pm 1.02$ & $26.64 \pm 1.06$ & -6.46 & $36.52 \pm 0.21$ & $35.92 \pm 0.18$ & -1.63 \\
\hline AQ $400 \mathrm{mg} / \mathrm{kg}$ & $27.52 \pm 0.68$ & $26.21 \pm 1.65$ & -5.03 & $36.34 \pm 0.14$ & $35.76 \pm 0.81$ & -1.51 \\
\hline EA $100 \mathrm{mg} / \mathrm{kg}$ & $31.73 \pm 0.90$ & $29.14 \pm 1.16$ & -7.32 & $36.42 \pm 0.26$ & $35.90 \pm 0.23$ & -1.79 \\
\hline EA $200 \mathrm{mg} / \mathrm{kg}$ & $29.40 \pm 0.76$ & $27.32 \pm 1.39$ & -7.07 & $36.37 \pm 0.16$ & $35.72 \pm 0.36$ & -1.79 \\
\hline EA $400 \mathrm{mg} / \mathrm{kg}$ & $32.57 \pm 1.36$ & $29.91 \pm 1.41$ & -8.15 & $36.20 \pm 0.23$ & $35.80 \pm 0.20$ & -1.10 \\
\hline $\mathrm{CH} 100 \mathrm{mg} / \mathrm{kg}$ & $31.15 \pm 0.45$ & $28.28 \pm 0.71$ & $-9.19^{\mathrm{b} 1}$ & $36.20 \pm 0.18$ & $34.92 \pm 0.31$ & $-3.54^{\mathrm{b} 3}$ \\
\hline $\mathrm{CH} 200 \mathrm{mg} / \mathrm{kg}$ & $29.43 \pm 1.13$ & $26.71 \pm 0.43$ & $-9.24^{\mathrm{bl}}$ & $35.95 \pm 0.22$ & $34.85 \pm 0.28$ & $-3.06^{\mathrm{b} 2}$ \\
\hline $\mathrm{CH} 400 \mathrm{mg} / \mathrm{kg}$ & $30.30 \pm 1.34$ & $27.63 \pm 1.09$ & $-8.81^{\mathrm{b} 1}$ & $35.82 \pm 0.23$ & $34.87 \pm 0.35$ & $-2.65^{\mathrm{b} 2}$ \\
\hline CQ $25 \mathrm{mg} / \mathrm{kg}$ & $26.19 \pm 1.11$ & $26.43 \pm 1.03$ & $0.92^{\mathrm{a} 3}$ & $35.92 \pm 0.28$ & $36.57 \pm 0.18$ & $1.81^{\mathrm{a} 3}$ \\
\hline
\end{tabular}

Data are expressed as mean $\pm \mathrm{SEM} ; n=6$, a = compared to distilled water, $\mathrm{b}=$ compared to chloroquine $25 \mathrm{mg} / \mathrm{kg}, 1=P<0.05,2=P<0.01,3=P<0.001$, $*$ = negative and positive controls used for crude extract in the 4 day suppressive test, $\mathrm{DW}=$ distilled water, $\mathrm{BA}=\mathrm{B}$. abyssinica crude extract, $\mathrm{EA}=$ ethyl acetate fraction, $\mathrm{CH}=$ chloroform fraction $\mathrm{AQ}=$ aqueous fraction, $\mathrm{CQ}=$ chloroquine, $\mathrm{SEM}=$ standard error of mean, $\mathrm{D} 0=$ day 0 , and $\mathrm{D} 4=$ day 4 .

TABLE 4: Effect of B. abyssinica crude extract and aqueous fraction on percentage parasitemia, and survival time of $P$. berghei-infected mice in Rane's test.

\begin{tabular}{|c|c|c|c|c|c|c|c|}
\hline \multirow{2}{*}{ Group } & \multicolumn{5}{|c|}{$\%$ parasitemia $( \pm$ SEM $)$} & \multirow{2}{*}{$\%$ suppression } & \multirow{2}{*}{ MST (days) } \\
\hline & D3 & D4 & D5 & D6 & D7 & & \\
\hline DW $10 \mathrm{ml} / \mathrm{kg}$ & $21.63 \pm 0.33$ & $23.72 \pm 0.68$ & $25.27 \pm 1.61$ & $27.12 \pm 0.78$ & $29.68 \pm 0.82$ & 0.00 & $8.17 \pm 0.48$ \\
\hline $\mathrm{BA} 100 \mathrm{mg} / \mathrm{kg}$ & $24.01 \pm 0.48$ & $24.30 \pm 0.70$ & $22.67 \pm 0.92^{\mathrm{b} 3}$ & $21.57 \pm 1.64^{\mathrm{b} 3}$ & $19.95 \pm 1.42^{\mathrm{a} 3, \mathrm{~b} 3}$ & $34.37^{\mathrm{a} 3, \mathrm{~b} 3}$ & $13.29 \pm 1.41^{\mathrm{b} 3}$ \\
\hline BA $200 \mathrm{mg} / \mathrm{kg}$ & $24.92 \pm 0.83$ & $24.07 \pm 1.00$ & $23.42 \pm 1.36^{\mathrm{b} 3}$ & $22.05 \pm 2.91^{\mathrm{b} 3}$ & $16.86 \pm 1.08^{\mathrm{a} 3, \mathrm{~b} 3}$ & $43.19^{\mathrm{a} 3, \mathrm{~b} 3}$ & $14.50 \pm 1.82^{\mathrm{a} 2, \mathrm{~b} 3}$ \\
\hline $\mathrm{BA} 400 \mathrm{mg} / \mathrm{kg}$ & $25.05 \pm 0.75$ & $24.13 \pm 0.76$ & $21.87 \pm 0.59^{\mathrm{b} 3}$ & $19.75 \pm 0.99^{\mathrm{b} 3}$ & $12.48 \pm 0.77^{\mathrm{a} 3, \mathrm{~b} 3, \mathrm{c} 3, \mathrm{~d} 1}$ & $57.94^{\mathrm{a} 3, \mathrm{~b} 3, \mathrm{c} 3, \mathrm{~d} 1}$ & $16.67 \pm 0.49^{\mathrm{a} 3, \mathrm{~b} 3}$ \\
\hline AQ $100 \mathrm{mg} / \mathrm{kg}$ & $24.88 \pm 0.62$ & $26.06 \pm 0.65^{\mathrm{b} 3}$ & $24.78 \pm 0.90^{\mathrm{b} 3}$ & $22.12 \pm 0.89^{\mathrm{b} 3}$ & $19.87 \pm 0.56^{\mathrm{a} 3, \mathrm{~b} 3}$ & $31.40^{\mathrm{a} 3, \mathrm{~b} 3}$ & $11.60 \pm 1.44^{\mathrm{b} 3}$ \\
\hline AQ $200 \mathrm{mg} / \mathrm{kg}$ & $24.73 \pm 0.97$ & $24.67 \pm 0.97^{\mathrm{b} 1}$ & $22.12 \pm 0.64^{\mathrm{b} 3}$ & $21.60 \pm 1.34^{\mathrm{b} 3}$ & $17.58 \pm 1.44^{\mathrm{a} 3, \mathrm{~b} 3}$ & $40.77^{\mathrm{a} 3, \mathrm{~b} 3}$ & $13.83 \pm 1.60^{\mathrm{a} 1, \mathrm{~b} 3}$ \\
\hline AQ $400 \mathrm{mg} / \mathrm{kg}$ & $25.18 \pm 0.80$ & $24.03 \pm 0.91^{\mathrm{b} 1}$ & $22.87 \pm 1.22^{\mathrm{b} 3}$ & $20.92 \pm 1.59^{\mathrm{b} 3}$ & $14.36 \pm 1.23^{\mathrm{a} 3, \mathrm{~b} 3, \mathrm{e} 2}$ & $51.62^{\mathrm{a} 3, \mathrm{~b} 3, \mathrm{e} 2}$ & $15.17 \pm 1.87^{\mathrm{a} 2, \mathrm{~b} 3}$ \\
\hline CQ $25 \mathrm{mg} / \mathrm{kg}$ & $22.68 \pm 0.78$ & $20.47 \pm 1.07^{\mathrm{a} 1}$ & $13.72 \pm 1.51^{\mathrm{a} 3}$ & $5.28 \pm 2.42^{\mathrm{a} 3}$ & $0.00 \pm 0.00^{\mathrm{a} 3}$ & $100.00^{\mathrm{a} 3}$ & $30.00 \pm 0.00^{\mathrm{a} 3}$ \\
\hline
\end{tabular}

Data are expressed as mean \pm SEM; $n=6$, a = compared to DW, b = compared to CQ $25 \mathrm{mg} / \mathrm{kg}, \mathrm{c}=$ compared to BA $100 \mathrm{mg} / \mathrm{kg}, \mathrm{d}=$ compared to BA $200 \mathrm{mg} /$ $\mathrm{kg}, \mathrm{e}=$ compared to AQ $100 \mathrm{mg} / \mathrm{kg}, 1=P<0.05,2=P<0.01,3=P<0.001, \mathrm{DW}=$ distilled water, $\mathrm{BA}=$ Bersama abyssinica crude extract, $\mathrm{AQ}=$ aqueous fraction, $\mathrm{CQ}=$ chloroquine, $\mathrm{SEM}=$ standard error of mean, $\mathrm{MST}=$ mean survival time, D3 = day $3, \mathrm{D} 4=$ day $4, \mathrm{D} 5=$ day $5, \mathrm{D} 6=$ day 6 , and $\mathrm{D} 7=$ day 7 .

Maximum inhibition (57.94\%) was attained with a $400 \mathrm{mg} / \mathrm{kg}$ dose of crude extract. The $400 \mathrm{mg} / \mathrm{kg}$ dose of the crude extract showed significant chemosuppression as compared with the $100 \mathrm{mg} / \mathrm{kg}(P<0.001)$ and $200 \mathrm{mg} / \mathrm{kg}(P<0.05)$ doses of crude extract. Likewise, a comparison among aqueous fraction-treated group revealed that $400 \mathrm{mg} / \mathrm{kg}$ dose showed significant parasite suppression $(P<0.01)$ as compared to the $100 \mathrm{mg} / \mathrm{kg}$ dose.

All doses in both the crude extract and aqueous fraction, except at $100 \mathrm{mg} / \mathrm{kg}$, significantly $(P<0.05-P<0.001)$ improved survival periods of the mice as compared to the negative control. However, comparison among extract dosetreated groups did not show any apparent difference in MST of mice (Table 4).

The effect of crude extract and aqueous fraction on packed cell volume is indicated in Figure 2. The decrease in PCV was significantly protected $(P<0.05$ and $P<0.01)$ by 200 and $400 \mathrm{mg} / \mathrm{kg}$ doses of both the crude extract and aqueous fraction as compared to the negative control, respectively. However, no significant protection was observed with $100 \mathrm{mg} / \mathrm{kg}$ dose of both the crude extract and aqueous fraction as compared to the negative control. Comparison among the test groups did not demonstrate noticeable differences in preventing PCV reduction.

As shown in Table 5, the loss in body weight and rectal temperature due to malaria infection was not significantly ameliorated by all doses of the crude extract and aqueous fraction as compared to the negative control. Similarly, comparison among crude extract-treated groups and also with respect to the standard drug did not show a statistically significant difference in the prevention of body weight and rectal temperature reduction.

3.5. Effect of Crude Extract and Aqueous Fraction in the Prophylactic Test. The crude extract and aqueous fraction 


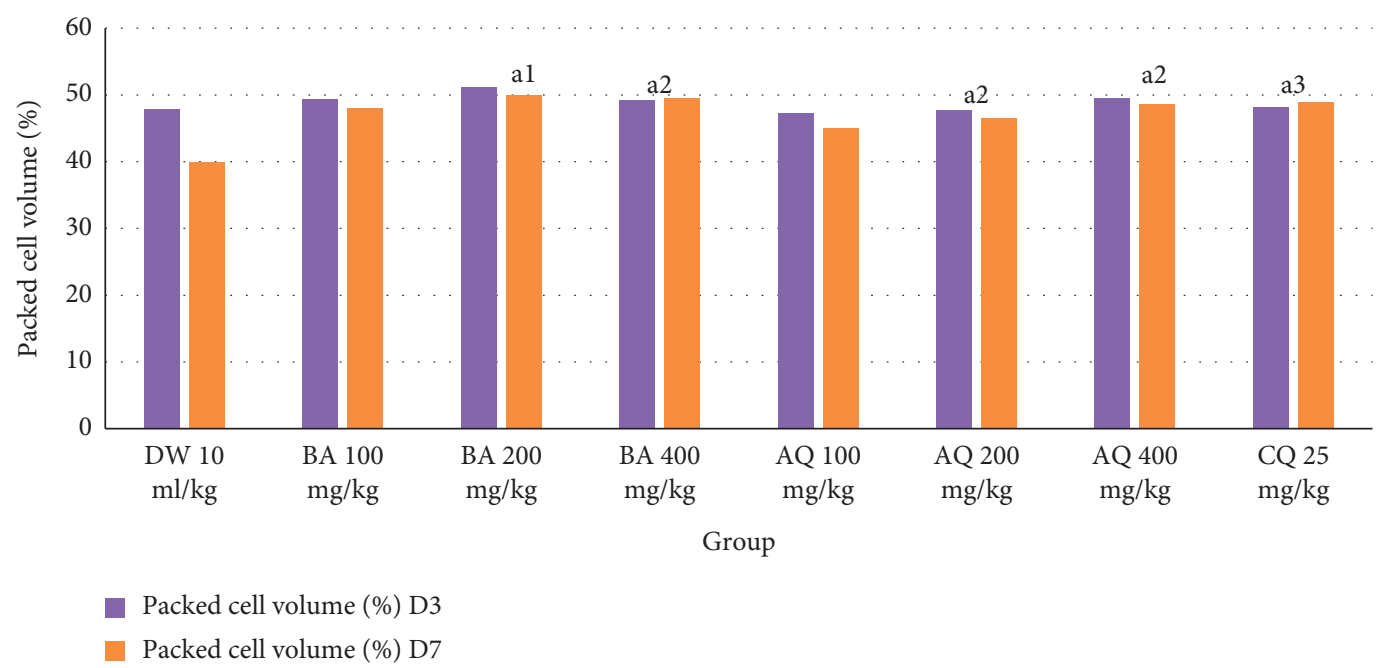

FIgURe 2: Effect of B. abyssinica crude extract and aqueous fraction on packed cell volume of $P$. berghei-infected mice in Rane's test. Data are expressed as mean \pm SEM; $n=6, a=$ compared to DW, $1=P<0.05,2=P<0.01,3=P<0.001$, DW distilled water, BA=Bersama abyssinica crude extract, $\mathrm{AQ}=$ aqueous fraction, $\mathrm{CQ}=$ chloroquine, $\mathrm{D} 3=$ day 3 , and $\mathrm{D} 7=$ day 7 .

TABle 5: Effect of B. abyssinica crude extract and aqueous fraction on body weight and rectal temperature of $P$. berghei-infected mice in Rane's test.

\begin{tabular}{|c|c|c|c|c|c|c|}
\hline \multirow{2}{*}{ Group } & \multicolumn{3}{|c|}{ Body weight $(\mathrm{g}) \pm \mathrm{SEM}$} & \multicolumn{3}{|c|}{ Rectal temperature $\left({ }^{\circ} \mathrm{C}\right) \pm \mathrm{SEM}$} \\
\hline & D3 & D7 & $\%$ change & D3 & D7 & $\%$ change \\
\hline DW $10 \mathrm{ml} / \mathrm{kg}$ & $24.84 \pm 1.86$ & $22.10 \pm 2.12$ & -11.03 & $35.17 \pm 0.18$ & $33.53 \pm 0.34$ & -4.64 \\
\hline BA $100 \mathrm{mg} / \mathrm{kg}$ & $25.90 \pm 0.47$ & $23.01 \pm 0.79$ & -10.45 & $35.37 \pm 0.37$ & $34.23 \pm 0.21$ & -3.17 \\
\hline BA $200 \mathrm{mg} / \mathrm{kg}$ & $27.84 \pm 0.64$ & $24.90 \pm 0.85$ & -10.56 & $35.65 \pm 0.37$ & $34.47 \pm 0.30$ & -3.28 \\
\hline BA $400 \mathrm{mg} / \mathrm{kg}$ & $28.74 \pm 0.95$ & $26.42 \pm 0.84$ & -8.07 & $36.00 \pm 0.28$ & $34.90 \pm 0.32$ & -3.04 \\
\hline AQ $100 \mathrm{mg} / \mathrm{kg}$ & $24.55 \pm 1.86$ & $22.54 \pm 0.64$ & -9.10 & $35.73 \pm 0.42$ & $34.26 \pm 0.30$ & -4.07 \\
\hline AQ $200 \mathrm{mg} / \mathrm{kg}$ & $27.28 \pm 0.94$ & $24.76 \pm 0.66$ & -9.24 & $35.35 \pm 0.25$ & $34.00 \pm 0.40$ & -3.79 \\
\hline AQ $400 \mathrm{mg} / \mathrm{kg}$ & $27.18 \pm 0.33$ & $25.44 \pm 1.21$ & -6.40 & $35.02 \pm 0.30$ & $33.93 \pm 0.53$ & -3.07 \\
\hline $\mathrm{CQ} 25 \mathrm{mg} / \mathrm{kg}$ & $28.37 \pm 1.16$ & $28.17 \pm 1.04$ & $-0.60^{\mathrm{a} 1}$ & $35.65 \pm 0.46$ & $36.36 \pm 0.26$ & $2.07^{\mathrm{a} 1}$ \\
\hline
\end{tabular}

Data are expressed as mean \pm SEM; $n=6$, a compared to DW, $1=P<0.05,2=P<0.01,3=P<0.001$, DW = distilled water, BA = Bersama abyssinica crude extract, $\mathrm{AQ}=$ aqueous fraction, $\mathrm{CQ}=$ chloroquine, $\mathrm{SEM}=$ standard error of the mean, $\mathrm{D} 3=$ day 3 , and $\mathrm{D} 7=$ day 7 .

had also shown dose-dependent chemoprophylactic activities against $P$. berghei-infected mice. All doses of the crude extract and aqueous fraction significantly suppressed $(P<0.01$ and $P<0.001)$ parasitemia as compared to the negative control. The $400 \mathrm{mg} / \mathrm{kg}$ dose of the crude extract showed significant prophylactic activity as compared with $100 \mathrm{mg} / \mathrm{kg}$ treated group. However, there were no significant differences in parasitemia suppression among the crude extract- and the aqueous fraction-treated mice. The standard drug induced a significant chemosuppression $(P<0.001)$ as compared with all doses of the crude extract and the aqueous fraction.

On the other hand, all doses of the crude extract $(P<0.05-P<0.001)$ as well as 200 and $400 \mathrm{mg} / \mathrm{kg}$ doses of the aqueous fraction $(P<0.05$ and $P<0.01)$ substantially prolonged survival time as compared to the negative control. Comparison among the crude extract dose-treated groups demonstrated that $400 \mathrm{mg} / \mathrm{kg}$ significantly prolongs $(P<0.05)$ the survival time as compared to $100 \mathrm{mg} / \mathrm{kg}$. However, the survival times of mice treated with the aqueous fraction doses did not show significant differences (Table 6).
As depicted in Figure 3, all doses of the crude extract and the aqueous fraction were able to significantly $(P<0.05$, $P<0.001)$ attenuate the reduction PCV in a dose-dependent manner as compared to the negative control. Comparison among crude- and aqueous fraction-treated groups including the standard drug revealed that there was no noticeable difference in the protection of packed cell volume.

Similar to the 4-day suppressive and curative tests, all doses of crude extract and aqueous fraction did not show significant protection against body weight and rectal temperature reduction as compared to the negative control. There were no considerable differences among all doses of the crude extract and aqueous fraction as well as with the standard drug in preventing body weight and rectal temperature reduction (Table 7).

\section{Discussion}

The present study explored the acute toxicity and antimalarial activity of the $80 \%$ methanolic leaf extract and solvent fractions of $B$. abyssinica against $P$. berghei infection in mice. 
TABLE 6: Effect of B. abyssinica crude extract and aqueous fraction on percentage parasitemia and survival time of $P$. berghei-infected mice in the prophylactic test.

\begin{tabular}{lccc}
\hline Treatment & \% parasitemia $( \pm$ SEM $)$ & $\%$ suppression & MST (days) $( \pm$ SEM $)$ \\
\hline DW $10 \mathrm{ml} / \mathrm{kg}$ & $30.30 \pm 1.30$ & 0.00 & $7.83 \pm 0.87$ \\
BA $100 \mathrm{mg} / \mathrm{kg}$ & $22.10 \pm 0.93$ & $27.06^{\mathrm{a} 3, \mathrm{~b} 3}$ & $11.33 \pm 0.71^{\mathrm{al}, \mathrm{b} 3}$ \\
BA $200 \mathrm{mg} / \mathrm{kg}$ & $19.65 \pm 1.22$ & $35.15^{\mathrm{a} 3, \mathrm{~b} 3}$ & $12.17 \pm 0.95^{\mathrm{a} 2, \mathrm{~b} 3}$ \\
BA $400 \mathrm{mg} / \mathrm{kg}$ & $16.93 \pm 1.00$ & $44.11^{\mathrm{a} 3, \mathrm{~b} 3, \mathrm{c} 2}$ & $14.67 \pm 0.88^{\mathrm{a} 3, \mathrm{~b} 3, \mathrm{c} 1}$ \\
AQ $100 \mathrm{mg} / \mathrm{kg}$ & $22.98 \pm 1.06$ & $24.16^{\mathrm{a} 2, \mathrm{~b} 3}$ & $9.83 \pm 1.45^{\mathrm{b} 3}$ \\
AQ $200 \mathrm{mg} / \mathrm{kg}$ & $21.20 \pm 0.75$ & $30.03^{\mathrm{a} 3, \mathrm{~b} 3}$ & $11.33 \pm 1.12^{\mathrm{a} 1, \mathrm{~b} 3}$ \\
AQ $400 \mathrm{mg} / \mathrm{kg}$ & $19.07 \pm 2.10$ & $37.07^{\mathrm{a} 3, \mathrm{~b} 3}$ & $13.50 \pm 1.65^{\mathrm{a} 2, \mathrm{~b} 3}$ \\
CQ $25 \mathrm{mg} / \mathrm{kg}$ & $0.30 \pm 0.18$ & $99.01^{\mathrm{a} 3}$ & $29.60 \pm 0.40^{\mathrm{a} 3}$ \\
\hline
\end{tabular}

Data are expressed as mean \pm SEM; $n=6, \mathrm{a}=$ compared to DW, $\mathrm{b}=$ compared to chloroquine $25 \mathrm{mg} / \mathrm{kg}, \mathrm{c}=$ compared to $\mathrm{BA} 100 \mathrm{mg} / \mathrm{kg}, 1=P<0.05$, $2=P<0.01,3=P<0.001, \mathrm{DW}=$ distilled water, $\mathrm{BA}=$ Bersama abyssinica crude extract, $\mathrm{AQ}=$ aqueous fraction, $\mathrm{CQ}=$ chloroquine, $\mathrm{SEM}=$ standard error of the mean, MST $=$ mean survival time.

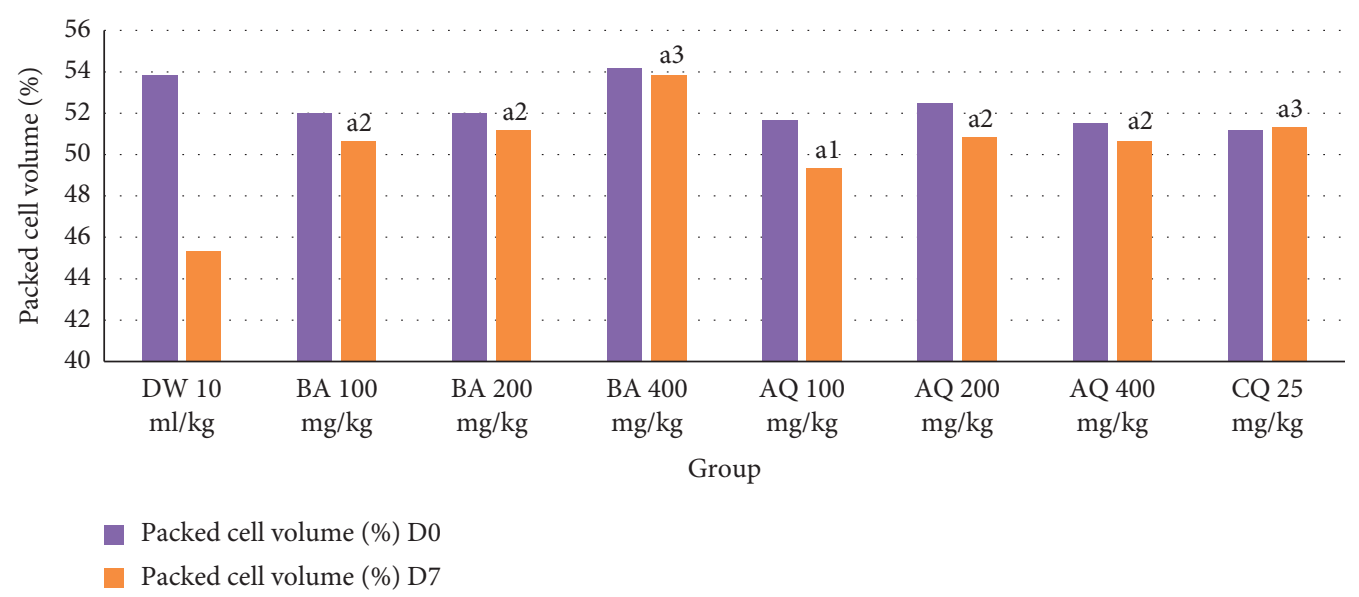

FIGURE 3: Effect of B. abyssinica crude extract and aqueous fraction on packed cell volume of $P$. berghei-infected mice in the prophylactic test. Data are expressed as mean $\pm \mathrm{SEM} ; n=6, \mathrm{a}=$ compared to DW, $1=P<0.05,2=P<0.01,3=P<0.001$, DW distilled water, $\mathrm{BA}=$ Bersama abyssinica crude extract, $\mathrm{AQ}=$ aqueous fraction, $\mathrm{CQ}=$ chloroquine, $\mathrm{D} 0=$ day 0 , and $\mathrm{D} 7=$ day 7 .

TABLE 7: Effect of B. abyssinica crude extract and aqueous fraction on body weight and rectal temperature of $P$. berghei-infected mice in the prophylactic test.

\begin{tabular}{|c|c|c|c|c|c|c|}
\hline \multirow{2}{*}{ Group } & \multicolumn{3}{|c|}{$\mathrm{Wt}(\mathrm{g}) \pm \mathrm{SEM}$} & \multicolumn{3}{|c|}{$\mathrm{T}\left({ }^{\circ} \mathrm{C}\right) \pm \mathrm{SEM}$} \\
\hline & D0 & D7 & $\%$ change & D0 & D7 & $\%$ change \\
\hline $\mathrm{DW} 10 \mathrm{ml} / \mathrm{kg}$ & $24.17 \pm 1.97$ & $21.41 \pm 0.91$ & -11.42 & $36.57 \pm 0.22$ & $34.85 \pm 0.28$ & -4.70 \\
\hline BA $100 \mathrm{mg} / \mathrm{kg}$ & $24.12 \pm 0.36$ & $22.10 \pm 0.62$ & -8.43 & $37.17 \pm 0.14$ & $36.18 \pm 0.24$ & -2.64 \\
\hline BA $200 \mathrm{mg} / \mathrm{kg}$ & $26.39 \pm 0.73$ & $24.16 \pm 0.68$ & -8.45 & $36.88 \pm 0.25$ & $36.03 \pm 0.15$ & -2.28 \\
\hline $\mathrm{BA} 400 \mathrm{mg} / \mathrm{kg}$ & $25.64 \pm 0.34$ & $23.58 \pm 0.40$ & -8.03 & $36.78 \pm 0.12$ & $35.97 \pm 0.20$ & -2.22 \\
\hline AQ $100 \mathrm{mg} / \mathrm{kg}$ & $23.36 \pm 0.58$ & $21.39 \pm 0.49$ & -8.46 & $36.65 \pm 0.14$ & $35.67 \pm 0.30$ & -2.68 \\
\hline AQ $200 \mathrm{mg} / \mathrm{kg}$ & $24.07 \pm 0.64$ & $22.09 \pm 0.78$ & -8.24 & $37.17 \pm 0.24$ & $36.25 \pm 0.16$ & -2.45 \\
\hline AQ $400 \mathrm{mg} / \mathrm{kg}$ & $25.67 \pm 1.29$ & $23.48 \pm 1.17$ & -8.30 & $37.20 \pm 0.21$ & $36.37 \pm 0.32$ & -2.23 \\
\hline $\mathrm{CQ} 25 \mathrm{mg} / \mathrm{kg}$ & $23.26 \pm 1.05$ & $23.85 \pm 1.16$ & $2.54^{\mathrm{a} 1}$ & $36.52 \pm 0.22$ & $36.72 \pm 0.17$ & $0.55^{\mathrm{a} 2}$ \\
\hline
\end{tabular}

Data are expressed as mean \pm SEM; $n=6, \mathrm{a}=$ compared to DW, $1=P<0.05,2=P<0.011,3=P<0.001$, DW $=$ distilled water, $\mathrm{BA}=$ Bersama abyssinica crude extract, $\mathrm{AQ}=$ aqueous fraction, $\mathrm{CQ}=$ chloroquine, $\mathrm{SEM}=$ standard error of mean, $\mathrm{MST}=$ mean survival time, $\mathrm{D} 0=$ day $0, \mathrm{D} 7=$ day $7, \mathrm{~T}=$ temperature, and $\mathrm{Wt}=$ body weight.

To account a possible prodrug effect and involvement of the immune system in the eradication of infection, antimalarial studies usually employ in vivo models as compared to in vitro studies [30]. Even though primate models provide a better prediction of the evaluation of the efficacy of antimalaria in humans, rodent models are used as a first step to screen most in vivo antimalarial activities of tested compounds [31]. The rodent models have been also validated through the identification of several conventional antimalarial agents such as chloroquine, halofantrine, mefloquine, and artemisinin derivatives [25,31]. It is also cost-effective in conducting preliminary pharmacological screening studies 
in rodent models than in primate models. The parasite $P$. berghei was used in this study since it is an appropriate parasite that is most commonly used because of its higher accessibility [31]. Due to the sensitivity and significant suppression of this parasite by chloroquine, this drug was employed as a standard [31].

The acute toxicity study revealed that the crude extract of B. abyssinica did not show mortality up to a dose of $2000 \mathrm{mg} /$ kg. Further physical and behavioral observations also revealed no visible signs of acute toxicity with the same dose. In general, this substance is considered a good candidate for further studies since its LD50 is 20 times more than the minimum effective dose tested $(100 \mathrm{mg} / \mathrm{kg})$ which satisfies the minimum requirement [32].

The antiplasmodial properties of the crude extract and solvent fractions of the leaves of $B$. abyssinica were investigated using standard models. Accordingly, a preliminary 4day suppressive test was conducted for the leaf extract of $B$. abyssinica to evaluate the schizonticidal activity and the percentage suppression of parasitemia of the crude extracttreated groups changed significantly from those in the negative control group. Thus, the plant is endowed with antimalarial activity and supports the previous reports of a moderate to pronounced in vitro antimalarial activity of leaf extracts of $B$. abyssinica $[16,17]$. The methanol extract of the leaves of Bersama engleriana, which is found in the same genus, was reported to have highly significant in vitro antimalarial activity with IC50 of $2.7 \mu \mathrm{g} / \mathrm{mL}$ [33], which further supports the result of this study. A compound is considered as active when the percentage suppression of parasitemia is $30 \%$ or more [34], which supports the findings of the current study.

Based on the preliminary suppressive effect, the crude extract was fractionated using three solvent systems (chloroform, ethyl acetate, and water) and evaluated through a 4day suppressive test on early Plasmodium infection. All fractions at all doses showed significant parasitemia suppression as compared to the negative control. All the three fractions displayed significant chemosuppressive activity suggesting that the active phytochemical constituent can be extracted by all three solvents or that the antimalarial effect is produced by more than one phytochemical constituent.

However, the relative variation in chemosuppressive activity might be due to variation in secondary metabolite contents, which suggests that the more potent antimalarial phytochemical quantitatively and/or qualitatively resides within semipolar and polar solvents. From previous phytochemical screening test [20], the methanol extract showed the presence alkaloids, flavonoids, glycosides, phenols, coumarins, anthraquinones, steroids, polysterols, and triterpenes, while the ethyl acetate extract showed the presence of alkaloids, flavonoids, glycosides, phenols, coumarins, and anthraquinones but the chloroform and petroleum ether extract only showed the presence of alkaloids, flavonoids, and glycosides which all are implicated in antimalarial activity [9]. Variation in the concentration of the right subgroups of phytoconstituents responsible for the antimalarial activity might also responsible for these insignificant differences in chemosuppressive activity. The methanol, ethyl acetate, and total aqueous extracts of B. abyssinica were also reported to show greater microbial growth inhibition than nonpolar extracts $[20,35,36]$ supporting that the biological activity of the plant lies in semipolar and polar extracts.

A fraction with highest the chemosuppression (aqueous fraction) in the 4-day suppressive test and the crude extract were further evaluated for their effect on established parasite infection using a curative test. Both the crude extract and aqueous fraction showed a significant $(P<0.001)$ curative effect at all doses as compared to the negative control with a maximum of $57.94 \%$ and $51.62 \%$ chemosuppression in the highest dose, respectively. This confirms that the plant material has effective antiplasmodial activity in the late stages of the infection. Like the standard drug, all treated groups, except $100 \mathrm{mg} / \mathrm{kg}$ dose of both the crude extract and the aqueous fraction, reduced parasitemia level after the first dose. This might be an indication of the comparative onset of defensive action of extracts and the standard drug. The delay of activity at $100 \mathrm{mg} / \mathrm{kg}$ dose of both the crude extract and the aqueous fraction might be due to the fact that the extracts at this dose had not been accumulated sufficiently to provoke considerable chemosuppression. Both the crude extract and the aqueous fraction showed dose-dependent curative antimalarial activity. The chemosuppressive effect on established infection was higher than the 4-day suppressive test, which might be due to the inhibitory effect of the extract on the generation of free radicals and hemolytic principles such as free fatty acids resulting from high parasitemia level [37].

After confirming the curative effect of the crude extract and the aqueous fraction, further evaluation was conducted to confirm their prophylactic potential, because some traditional plants which showed antiplasmodial activity in 4day suppressive and curative tests also showed prophylactic activity against the $P$. berghei parasite [38]. In this study, the crude extract of $B$. abyssinica and the aqueous fraction had shown significant chemoprophylactic activity against residual infection at all doses as compared to the negative control with maximum parasitemia chemosuppression of $44.11 \%$ and $37.07 \%$, respectively, at the highest dose.

The percentage suppression in the prophylactic test was found to be low as compared to 4-day suppressive and curative tests. This might have arisen from rapid hepatic clearance or metabolism of the active component responsible for antimalarial activities due to the administration of the extract initially for four days before inoculation with $P$. berghei parasite. The lower efficacy of the crude extract and fractions might be in part due to unpurified/crude nature, low selectivity, slow absorption, and poor bioavailability or other pharmacokinetic and pharmacodynamic limitations [6].

The mean survival time is another important parameter to evaluate the antimalarial activity of plant extracts [31]. In this study, the crude extract and all fractions, except the chloroform fraction, significantly prolong the mean survival time as compared to the negative control especially at higher doses in all tested models. This further supplements the evidence on the suppression of $P$. berghei, resulting in a reduced overall pathologic effect of the parasite on the study mice [39]. The mean survival time of mice treated with the 
standard drug was significantly prolonged $(P<0.001)$ as compared to the entire doses of the crude extract- and solvent fraction-treated groups in all models; this might be due to the fast elimination phase or less potency of the extracts. A plant material that can prolong the survival time of infected experimental animals compared to the negative control is considered as active against malaria. A principle compound that prolonged survival time beyond 12 days is regarded as active [40].

Packed cell volume reduction is one feature of malariainfected mice. It was measured to evaluate the effectiveness of the crude extract and fractions in preventing hemolysis due to the rising parasitemia level [41]. Escalating parasitemia causes the clearance and/or destruction of infected RBCs, the clearance of uninfected RBCs, and erythropoietic suppression and dyserythropoiesis. These mechanisms have been implicated in both human and mouse malarial anemia [42]. Plants with antimalarial activity are expected to prevent a reduction in packed cell volume secondary to preventing hemolysis. Interestingly, it was noted that, in 4day suppressive and prophylactic tests, all doses of the crude extract and solvent fractions showed significant protection in packed cell volume. In the curative test, the 200 and $400 \mathrm{mg} / \mathrm{kg}$ doses of both crude extract and the aqueous fraction also showed significant protection in packed cell volume reduction as compared with the negative control. The prevention of packed cell volume reduction might be as a result of the destructive antiplasmodial effect of the crude extract and fractions against the parasitized RBCs and the causative parasite, thereby sustaining the availability of the new RBCs produced in the bone marrow, or this might be due to the absence of saponins, which are known as phytodetergents that induce cholesterol liberation from the cell membrane and increase the permeability of the plasma membrane of the RBCs ending up with strong hemolytic effects $[43,44]$.

Body weight loss and rectal temperature reduction are other manifestations of rodent malaria infections that develop because of the intensity of the infection [44]. These reductions resulting from a rise in parasitemia are expected to be prevented by plants with antimalarial activity. Unfortunately, the entire doses of crude extract and solvent fractions did not prevent body weight loss and rectal temperature reduction in all tested models, even though there was significant suppression of parasitemia. This indicates the involvement of other factors for these reductions beyond malaria infection. For example, the weight loss might be due to catabolic activity on stored lipids or anorexigenic effect that may have led to decreased food intake due to the presence of appetite-suppressant metabolites in the crude extract and fractions, in addition to disturbed metabolic function and hypoglycemia related to malaria infection [39]. This appetite suppressive activity might be ascribed to flavonoids, glycosides, and phenolic compounds found in the extract [44].

On the other hand, the reduction in rectal temperature might be due to less hypothermic effect on the extracttreated mice which is supported by the use of this plant for fever management traditionally [45], in addition to the probable inability of the plant extract to ameliorate some pathological processes of malaria that cause reduction in rectal temperature or the reduction in metabolic rates that occur because of increased parasitemia [29].

Secondary metabolites have been implicated in antiplasmodial activity through different possible mechanisms including endoperoxidation by sesquiterpenes and monoterpenes [46], intercalation in DNA by anthraquinones [47], disruption of the parasite ability of detoxifying heme into nontoxic malaria pigment by alkaloids [48], blocking of protein synthesis by alkaloids and chelation with nucleic acid base pairing by flavonoids [49], immunomodulatory effects by phytosteroids and flavonoids [50], reduction of the activity of superoxide dismutase (SOD) and inhibition of the synthesis of DNA by coumarins [51], free radical scavenging effects by tannins [52], antioxidant effect by phenols like flavonoids due to their redox properties which allow them to act as reducing agents, metal chelators, and free radical quenchers $[53,54]$, or by any other unknown mechanisms. The antioxidative activity can inhibit haem polymerization as haem has to be oxidized before polymerization, and the unpolymerized haem is very toxic for the intraerythrocytic plasmodia [55]. The extracts could have elicited its action through any of the abovementioned mechanisms or by some other means yet to be determined. Therefore, the antiplasmodial activity observed in this plant could have resulted from a single or combined action of these metabolites.

According to Deharo et al. [56], in vivo antimalarial activity of plant extracts can be categorized as moderate, good, and very good if the extract showed $50 \%$ or more chemosuppression at 500, 250, and $100 \mathrm{mg} / \mathrm{kg} /$ day extract dose, respectively. Based on this rating, $80 \%$ methanolic leaf extract of B. abyssinica and solvent fractions have barely moderate antimalarial activity in 4-day suppressive and prophylactic tests, as none of the active doses met the threshold $50 \%$ or more inhibition, but in the curative test, both the crude extract and the aqueous fraction at $400 \mathrm{mg} / \mathrm{kg}$ dose provided a parasite suppression of $>50 \%$, exhibiting a moderate antiplasmodial activity.

\section{Conclusion}

From the results of this study, it can be concluded that the plant extract is relatively safe to mice and also showed fairly moderate antimalarial activity in early, established, and residual infections. Among fractions, the aqueous fraction showed relatively highest parasitemia suppression. The crude extract and the aqueous fraction significantly suppress parasitemia, thereby protecting the packed cell volume and prolonging the mean survival time, but failed in the prevention of rectal temperature and body weight reduction in all tested models. The overall results of this study illustrated that the leaf extracts of $B$. abyssinica have moderate antimalarial activity, and this may entail isolation and advanced safety and efficacy tests. Generally, the present pharmacological evidence provides support for the folklore claim of $B$. abyssinica leaves as an antimalarial agent and the results from previous in vitro studies on the antimalarial activity of the plant. 


\section{Abbreviations}

PCV: $\quad$ Packed cell volume

RBC: $\quad$ Red blood cell

SEM: Standard error of the mean

OECD: Organization for Economic Cooperation

ILAR: Institute for Laboratory Animal Research.

\section{Data Availability}

The datasets used and/or analyzed during the current study are available from the corresponding author upon reasonable request.

\section{Ethical Approval}

The study protocol was submitted and approved by the research ethics committee of the School of Pharmacy, University of Gondar, and the experiment was conducted in accordance with the guide for the care and use of laboratory animals. Ethical clearance was requested and approved by the ethical committee of the College of Health Sciences, Wollega University, Ethiopia.

\section{Conflicts of Interest}

The authors declared that there are no conflicts of interest.

\section{Authors' Contributions}

All authors contributed to the design and the writing of the manuscript. AAA performed the laboratory procedures and statistical analysis and interpreted the data under the supervision of EMB and JSY. All authors read and approved the final manuscript.

\section{Acknowledgments}

There was financial support to purchase laboratory animals and chemicals from the Amhara National Regional State Health Bureau. The authors are pleased to acknowledge the Amhara National Regional State Health Bureau and the University of Gondar for allowance.

\section{References}

[1] S. Jana and J. Paliwal, "Novel molecular targets for antimalarial chemotherapy," International Journal of Antimicrobial Agents, vol. 30, no. 1, pp. 4-10, 2007.

[2] WHO, World Malaria Report 2019, WHO, Geneva, Switzerland, 2019.

[3] C. Gryseels, K. Peeters Grietens, S. Dierickx et al., "High mobility and low use of malaria preventive measures among the jarai male youth along the Cambodia-Vietnam border," The American Journal of Tropical Medicine and Hygiene, vol. 93, no. 4, pp. 810-818, 2015.

[4] H. S. Taffese, "Malaria epidemiology and interventions in Ethiopia from 2001 to 2016," Infectious Diseases of Poverty, vol. 7, no. 1, p. 103, 2018.

[5] FMOH, National Strategic Plan for Malaria Prevention, Control and Elimination in Ethiopia, 2011-2015, FMOH, Addis Ababa, Ethiopia, 2015.
[6] E. Unekwuojo, J. Omale, and A. R. Olubunmi, "Suppressive, curative and prophylactic potentials of Morinda lucida (Benth) against erythrocytic stage of mice infective chloroquine sensitive Plasmodium berghei NK-65," British Journal of Applied Science \& Technology, vol. 1, no. 3, pp. 131-140, 2011.

[7] P. A. Tarkang, R. Appiah-Opong, M. F. Ofori, L. S. Ayong, and A. K. Nyarko, "Application of multi-target phytotherapeutic concept in malaria drug discovery: a systems biology approach in biomarker identification," Biomarker Research, vol. 4, no. 1, p. 25, 2016.

[8] A. B. Oliveira, M. F. Dolabela, F. C. Braga, R. L. R. P. Jácome, F. P. Varotti, and M. M. Póvoa, "Plant-derived antimalarial agents: new leads and efficient phythomedicines. Part I. Alkaloids," Anais da Academia Brasileira de Ciências, vol. 81, no. 4, pp. 715-740, 2009.

[9] Department of International Development, Medicines for malaria venture (MMV) 2005-2010. MMV in Natural Products: Harnessing the Power of Nature in Malaria Drug Discovery, Department of International Development, London, UK, 2009.

[10] S. Suleman, T. Beyene Tufa, D. Kebebe et al., "Treatment of malaria and related symptoms using traditional herbal medicine in Ethiopia," Journal of Ethnopharmacology, vol. 213, pp. 262-279, 2018.

[11] S. Kumar and A. K. Pandey, "Chemistry and biological activities of flavonoids: an overview," The Scientifc World Journal, vol. 2013, p. 16, 2013.

[12] K. Karunamoorthi and E. Tsehaye, "Ethnomedicinal knowledge, belief and self-reported practice of local inhabitants on traditional antimalarial plants and phytotherapy," Journal of Ethnopharmacology, vol. 141, no. 1, pp. 143-150, 2012.

[13] S. Asnake, T. Teklehaymanot, A. Hymete, B. Erko, and M. Giday, "Survey of medicinal plants used to treat malaria by Sidama people of Boricha district, Sidama zone, South region of Ethiopia," Evidence-Based Complementary and Alternative Medicine, vol. 2016, Article ID 9690164, 9 pages, 2016.

[14] R. S. Nondo, Z. Denis, J. M. Mainen et al., "Ethnobotanical survey and in vitro antiplasmodial activity of medicinal plants used to treat malaria in Kagera and Lindi regions, Tanzania," Journal of Medicinal Plants Research, vol. 9, no. 6, pp. 179-192, 2015.

[15] S. Okello, R. O. Nyunja, G. W. Netondo, and J. C. Onyango, "Ethnobotanical study of medicinal plants used by Sabaots of Mt. Elgon Kenya," African Journal of Traditional, Complementary and Alternative Medicines, vol. 7, no. 1, 2010.

[16] G. N. Zirihi, L. Mambu, F. Guédé-Guina, B. Bodo, and P. Grellier, "In vitro antiplasmodial activity and cytotoxicity of 33 West African plants used for treatment of malaria," Journal of Ethnopharmacology, vol. 98, no. 3, pp. 281-285, 2005.

[17] M. Kassa, R. Mohana, and A. Hunde, "Antimalarial activity of Bersama abyssinica against plasmodium falciparum," Ethiopian Pharmaceutical Journal, vol. 14, pp. 16-21, 1996.

[18] OCED, The OECD guidelines for the testing of chemicals: repeated dose 28-day oral toxicity study in rodents," Testing Guidelines, vol. 407, pp. 1-13, 2008.

[19] Institute for Laboratory Animal Research (ILAR), Guide for the Care and Use of Laboratory Animals, National Academy Press, Washington, DC, USA, 1996.

[20] F. W. Mathewos Anza, L. Solomon, and F. Mamo, "Milkyas endale phytochemical screening and antibacterial activity of leaves extract of bersama abyssinica," Journal of Advanced Botany and Zoology, vol. 3, no. 2, 2015. 
[21] M. Ayaz, M. Junaid, J. Ahmed et al., "Phenolic contents, antioxidant and anticholinesterase potentials of crude extract, subsequent fractions and crude saponins from Polygonum hydropiper L," BMC Complementary and Alternative Medicine, vol. 14, no. 1, p. 145, 2014.

[22] OECD, The OECD Guidelines for Testing of chemicals, Acute Oral Toxicity: up- and-Down Procedure, OECD, Paris, France, 2008.

[23] J. E. Okokon, I. A. Effiong, and E. Ettebong, "In vivo antimalarial activities of ethanolic crude extracts and fractions of leaf and root of Carpolobia lutea," Pakistan Journal of Pharmaceutical Sciences, vol. 24, no. 1, pp. 57-61, 2011.

[24] D. J. Knight and W. Peters, "The antimalarial activity of N-benzyloxydihydrotriazines," Annals of Tropical Medicine \& Parasitology, vol. 74, no. 4, pp. 393-404, 1980.

[25] J. F. Ryley and W. Peters, "The antimalarial activity of some quinolone esters," Annals of Tropical Medicine \& Parasitology, vol. 64, no. 2, pp. 209-222, 1970.

[26] W. Peters, "Drug resistance in plasmodium berghei," Experimental Parasitology, vol. 17, no. 1, pp. 80-89, 1965.

[27] N. Aarthi and K. Murugan, "Antimalarial activity and phytochemical screening of ethanolic leaf extract of Phyllanthus niruri and Mimosa pudica," IJPRD, vol. 3, no. 3, p. 24, 2011.

[28] B. Mengiste, E. Makonnen, and K. Urga, "Invivo antimalarial activity of Dodonaea Angustifolia seed extracts against Plasmodium berghei in mice model," Momona Ethiopian Journal of Science, vol. 4, no. 1, pp. 47-63, 2012.

[29] D. Dikasso, E. Makonnen, A. Debella et al., "In vivo antimalarial activity of hydroalcoholic extracts from Asparagus africanus Lam. in mice infected with Plasmodium berghei," Ethiopian Journal of Health Development, vol. 20, no. 2, pp. 112-118, 2006.

[30] A. Hilou, O. G. Nacoulma, and T. R. Guiguemde, "In vivo antimalarial activities of extracts from Amaranthus spinosus L. and Boerhaavia erecta L. in mice," Journal of Ethnopharmacology, vol. 103, no. 2, pp. 236-240, 2006.

[31] D. A. Fidock, P. J. Rosenthal, S. L. Croft, R. Brun, and S. Nwaka, "Antimalarial drug discovery: efficacy models for compound screening. Supplementary documents," Nature Reviews Drug Discovery, vol. 3, no. 6, pp. 509-520, 2004.

[32] A. Uwakwe and C. Monago, "Antiplasmodial activity of methanolic stem bark extract of Anthocleista grandiflora in mice," International Journal of Applied, vol. 2, no. 4, 2012.

[33] M. Ngemenya, "Antiplasmodial activity and toxicity of extracts and products from selected medicinal plants used in Cameroon [MIM-MN-187588]," in Acta Tropica, Vol. 211, Elsevier Science, Amsterdam, Netherlands, 2005.

[34] M. Adugna, "In vivo antimalarial activity of crude extract of aerial part of Artemisia abyssinica against Plasmodium berghei in mice," Global Journal Pharmacology, vol. 8, no. 3, pp. 460-468, 2014.

[35] G. Bolou, I. Bagré, K. Ouattara, and A. J. Djaman, "Evaluation of the antibacterial activity of 14 medicinal plants in Côte d'Ivoire," Tropical Journal of Pharmaceutical Research, vol. 10, no. 3, 2011.

[36] N. Zekeya, F. Shahada, and M. Chacha, "In vitro antibacterial and antifungal activity of Tanzanian Bersama abyssinica," International Journal of Science and Research, vol. 3, pp. 1150-1153, 2014.

[37] L. Carvalho, M. G. Brandão, D. Santos-Filho, J. L. Lopes, and A. U. Krettli, "Antimalarial activity of crude extracts from Brazilian plants studied in vivo in Plasmodium berghei-infected mice and in vitro against Plasmodium falciparum in culture," Brazilian Journal of Medical and Biological
Research = Revista Brasileira de Pesquisas Medicas e Biologicas, vol. 24, no. 11, pp. 1113-1123, 1991.

[38] O. A. Salawu, "Antimalarial activity of ethanolic stem bark extract of Faidherbia Albida (Del) a. Chev (Mimosoidae) in mice," Archives Applied Science Research, vol. 2, no. 5, pp. 261-268, 2010.

[39] R. Basir, S. F. Rahiman, K. Hasballah et al., "Plasmodium berghei ANKA infection in ICR mice as a model of cerebral malaria," Iranian Journal of Parasitology, vol. 7, no. 4, pp. 62-74, 2012.

[40] I. Ural, H. Kayalar, C. Durmuskahya, I. Cavus, and A. Ozbilgin, "In vivo antimalarial activity of methanol and water extracts of Eryngium thorifolium Boiss (Apiaceae Family) against P. berghei in infected mice," Tropical Journal of Pharmaceutical Research, vol. 13, no. 8, pp. 1313-1317, 2014.

[41] J. E. Okokon, B. N. Ita, and A. E. Udokpoh, "The in-vivo antimalarial activities of Uvaria chamae and Hippocratea africana," Annals of Tropical Medicine \& Parasitology, vol. 100, no. 7, pp. 585-590, 2006.

[42] A. A. Lamikanra, D. Brown, A. Potocnik, C. Casals-Pascual, J. Langhorne, and D. J. Roberts, "Malarial anemia: of mice and men,” Blood, vol. 110, no. 1, pp. 18-28, 2007.

[43] K. Kaur, M. Jain, T. Kaur, and R. Jain, "Antimalarials from nature," Bioorganic \& Medicinal Chemistry, vol. 17, no. 9, pp. 3229-3256, 2009.

[44] J. W. Yun, "Possible anti-obesity therapeutics from nature-A review," Phytochemistry, vol. 71, no. 14-15, pp. 1625-1641, 2010.

[45] H. O. Edeoga, D. E. Okwu, and B. O. Mbaebie, "Phytochemical constituents of some Nigerian medicinal plants," African Journal of Biotechnology, vol. 4, no. 7, pp. 685-688, 2005.

[46] E. Hatzakis, I. Opsenica, B. A. Solaja, and M. Stratakis, "Synthesis of novel polar derivatives of the antimalarial endoperoxides ascaridole and dihydroascaridole," Arkivoc, vol. 8, pp. 124-135, 2007.

[47] G. Geremedhin, D. Bisrat, and K. Asres, "Isolation, characterization and in vivo antimalarial evaluation of anthrones from the leaf latex of Aloe percrassa Todaro," Journal of Natural Remedies, vol. 14, no. 2, pp. 119-125, 2014.

[48] J. B. C. Soares, D. Menezes, M. A. Vannier-Santos et al., "Interference with hemozoin formation represents an important mechanism of schistosomicidal action of antimalarial quinoline methanols," PLoS Neglected Tropical Diseases, vol. 3, no. 7, p. e477, 2009.

[49] J. E. Okokon, E. O. Etebong, J. A. Udobang, and J. Obot, "Antiplasmodial and antiulcer activities of Melanthera scadens," Asian Pacific Journal of Tropical Biomedicine, vol. 2, no. 1, pp. 16-20, 2012.

[50] S. Aherne, T. Daly, T. O'Connor, and N. O'Brien, "Immunomodulatory effects of $\beta$-sitosterol on human Jurkat T cells," Planta Medica, vol. 73, no. 9, p. P_011, 2007.

[51] L. Mu, Q. Wang, and Y. Ni, "Effect of daphnetin on SOD activity and DNA synthesis of Plasmodium falciparum in vitro," Zhongguo Ji Sheng Chong Xue Yu Ji Sheng Chong Bing Za Zhi = Chinese Journal of Parasitology \& Parasitic Diseases, vol. 21, no. 3, pp. 157-159, 2003.

[52] S. A. Adesegun, G. Ayoola, H. A. Coker et al., "Phytochemical screening and antioxidant activities of some selected medicinal plants used for malaria therapy in Southwestern Nigeria," Tropical Journal of Pharmaceutical Research, vol. 7, no. 3, pp. 1019-1024, 2008.

[53] B. Ifesan, "Antioxidant and antimicrobial properties of selected plant leaves," European Journal of Medicinal Plants, vol. 3, no. 3, pp. 465-473, 2013. 
[54] G. Oboh and J. B. T. Rocha, "Polyphenols in red pepper [Capsicum annuum var. aviculare (Tepin)] and their protective effect on some pro-oxidants induced lipid peroxidation in brain and liver," European Food Research and Technology, vol. 225, no. 2, pp. 239-247, 2007.

[55] D. Taramelli, D. Monti, N. Basilico, S. Parapini, F. OmodeoSalé, and P. Olliaro, "A fine balance between oxidised and reduced haem controls the survival of intraerythrocytic plasmodia," Parassitologia, vol. 41, no. 1-3, pp. 205-208, 1999.

[56] E. Deharo, G. Bourdy, C. Quenevo, V. Muñoz, G. Ruiz, and M. Sauvain, "A search for natural bioactive compounds in Bolivia through a multidisciplinary approach. Part V. Evaluation of the antimalarial activity of plants used by the Tacana Indians," Journal of Ethnopharmacology, vol. 77, no. 1, pp. 91-98, 2001. 